
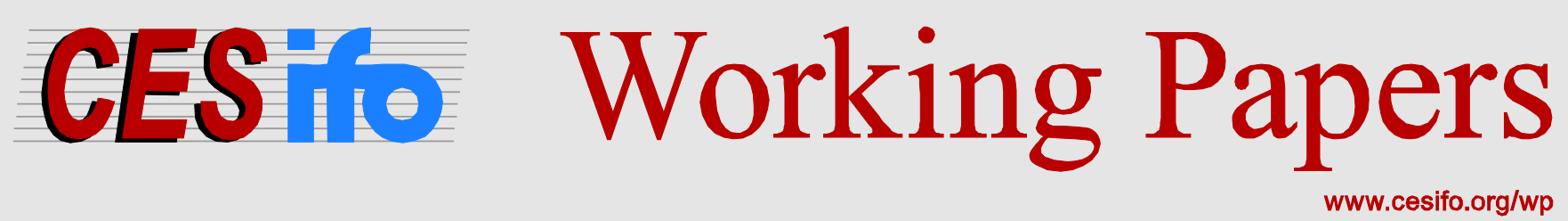

\title{
The Historical Roots of Corruption and Economic Development in Italy
}

\author{
Ilaria Petrarca \\ Roberto Ricciuti
}

CESIFO WORKING PAPER NO. 4212

CATEgory 2: Public CHOICE

APRIL 2013

An electronic version of the paper may be downloaded

- from the SSRN website:

- from the RePEc website:

- from the CESifo website:

WWW.SSRN.com

Www.RePEc.org

www.CESifo-group.org/wp

\section{CESifo}




\title{
The Historical Roots of Corruption and Economic Development in Italy
}

\begin{abstract}
We claim that a sequential mechanism linking history to development exists: first, history defines the quality of social capital; then, social capital determines the level of corruption; finally, corruption affects economic performance. We test this hypothesis on a dataset of Italian provinces, and address the possible endogeneity of corruption by applying an IV model. We use three sets of historical instruments for corruption: 1) foreign dominations in 16th-17th century, 2) autocracy/autonomous rule in the 14th century, and 3) an index of social capital between in the 19th-20th century. The results indicate a significant impact of historically-driven corruption on development.
\end{abstract}

JEL-Code: D730, O120, O430, C260.

Keywords: corruption, economic development, institutions, social capital, history.

Ilaria Petrarca

University of Verona

Verona / Italy

ilaria.petrarca@univr.it
Roberto Ricciuti

Department of Economics

University of Verona

Vicolo Campofiore 2

Italy - 37129 Verona

roberto.ricciuti@univr.it 


\section{Introduction}

The economic growth literature has witnessed three main strands of research. The first in the "50s and '60s was primarily concerned with the accumulation of capital with diminishing returns, along Solovian lines. The second, in the ' 80 s and ' $90 \mathrm{~s}$, was concerned with the policies that governments may implement in order to achieve sustained growth, in a world of increasing returns to scale. More recently, the emphasis has moved on the effects of institutions (and governance) on economic growth.

The literature has so far studied the direct link either between corruption and economic growth and between history and economic development; nonetheless, there exist a sequential mechanism linking history to development: first, history defines the quality of social capital; then, social capital determines the level of corruption; finally, corruption affects economic performance. Italy is a suitable testing ground since it shows high variations in per capita income, has a long history of dominations and self-government, and displays high level of corruption. Therefore, We empirically test our hypothesis on a dataset of Italian provinces, and address the possible endogeneity of corruption by applying an Instrumental Variables model. We alternatively use three sets of historical instruments for corruption: 1) foreign dominations that ruled Italian regions between the $16^{\text {th }}$ and $17^{\text {th }}$ century, 2) autocracy/autonomous rule in the $14^{\text {th }}$ century, and 3) an index of social capital between the end of the $19^{\text {th }}$ and at the onset of the $20^{\text {th }}$ century. The results confirm the validity of the set of instruments 2) and 3), and indicate a significant impact of historically-driven corruption on current development.

The paper is organized as follows. Section 2 reviews the literature on the interplay between institutions, their history and their consequences, in particular with respect to the (bad) quality of governance, of which corruption is one of the symptoms. Section 3 presents the methodology and the data we use, whereas results are discussed in Section 4. Section 5 concludes.

\section{History, institutions and corruption}

The role of institutions and history has been analyzed in the economic literature in the framework defined by the works of March and Olson (2006), La Porta et al. (1998, 1999), Glaeser et al. (2004), Acemoglu and Robinson (2008, 2012), and Besley and Persson (2009). They maintain that there is a link between the quality of institutions, the efficiency of the public policies and the wellbeing of the countries. Institutions are considered as a collection 
of rules, norms, practices and customs that regulate the life in common and the behaviors of citizens (March and Olsen, 2006). In particular, institutions play a key role in setting incentives, solve conflicts among sections of the societies, and allow new emerging groups to substitute old ones without violence. As in Acemoglu (2005) and Acemoglu and Robinson (2008, 2012), closed and conservative elites act to avoid the transformation and the openness of the social norms, limiting the access of the newest and more dynamic socio-economic groups. The closure of the process of norms transformation - i.e., the establishment of extractive institutions has strong effects on the capability to implement pro-business policies, reforms, infrastructure improvements and structural innovation. This could limit international competitiveness, economic activities and the establishment of a fair social equilibrium. ${ }^{1}$

In a series of influential articles, Daron Acemoglu, Simon Johnson and James Robinson addressed the issue of differences in development levels putting forward an institutionalist theory based on three main tenets (Acemoglu et al., 2001: 1370). The first hypothesis is concerned with different types of colonization: in colonies where Europeans were mainly interested in expropriating resources (e.g., Congo), institutions did not enforced neither private property nor checks and balances in order to tame expropriation from the government. Instead, where Europeans migrated and founded colonies, they designed institutions that protected private property and contracts (as in the US, Canada, New Zealand and Australia). The second hypothesis claims that European settlements were influenced by the environment: colonizers moved to relatively safe areas and implemented effective institutions. Where this was impossible (for example, because of malaria) expropriation was the policy. Third, institutions show considerable inertia, therefore they were kept in place after decolonization. In this view, based on econometric and anecdotal evidence, ${ }^{2}$ French and Spanish colonization were mainly expropriatory, destroyed indigenous institutions, causing per capita GDP to stagnate also after decolonization.

The quality of institutions affects economic activities via some specific channels, largely analyzed in the literature. For example, Mauro (1995) and Tanzi (1998) analyze the

\footnotetext{
${ }^{1}$ The role of institutions over geography and trade as the main determinant of growth has been put forward by Rodrick et al. (2004). Glaeser et al. (2004) have an opposite view, claiming that human capital is more important than institutions for growth.

${ }^{2}$ For the econometric evidence see Acemoglu et al. (2001), for anecdotal evidence see Acemoglu et al. (2003) where the success story of Botswana (in which British colonizers did not interfere much with local institutions) is contrasted with French and Spanish experiences.
} 
effects of corruption and invasive bureaucracy on economic development, via the collapse of the private investments. Knack and Keefer (1995) analyze the effect on the growth of the weak protection of the property rights. Krueger (1974) examined the problem of rent-seeking activities and its effect on the wellbeing of the society. La Porta et al. (1998) study the relations between the law origins and the financing methods used by the firm and business activities, considering the strong effect on the economic development.

The judicial system and the regulatory authorities are an important pillar in the quality of governance, and to contrast corruption. In Shleifer and Vishny (1993), a weak state capacity and the lack of regulation open sizable opportunities for negative behaviors by state agencies and bureaucratic sectors, as corruption or resource waste. Djankov et al. (2003) analyze the role of the courts, theorizing that less efficient courts are linked with corruption and rent-seeking activities.

\section{Methodology and data}

Our aim is to study the role of historically-driven corruption in determining the current level of development of Italian regions. The transmission mechanism that we suggest is one in which history determines the quality of social capital and the level of corruption, that in turn affects economic development. Figure 1 shows the provincial level of per-capita value added (averaged 2004-2007) by quartile. There is a well-known North-South divide, with the provinces in the highest quartile being concentrated in the North, and those belonging to the lowest in the South. A remarkable exception is Lazio, that is located in the central part of the peninsula but belongs to the highest quartile of the distribution. The existence of this outlier is motivated with the fact this is the Region where the national capital Rome is located, therefore it benefits from being close to the administrative centre of the country.

Time series data on corruption in Italy are not available at the provincial level ${ }^{3}$, but Fiorino et al. (2012) show a very high correlation between corruption and regional associate crime, therefore we use the former as a proxy ${ }^{4}$. Figure 2 provides the territorial distribution of the quartiles of the distribution of provincial corruption per million of inhabitants. Again a similar North-South pattern emerges, with corruption being concentrated in the South.

\footnotetext{
${ }^{3}$ ISTAT started collecting provincial data only in 2010.

${ }^{4}$ For a theoretical link between corruption and associate crime see Krugler et al. (2004).
} 
Figure 1 - Per capita value added in Italian provinces

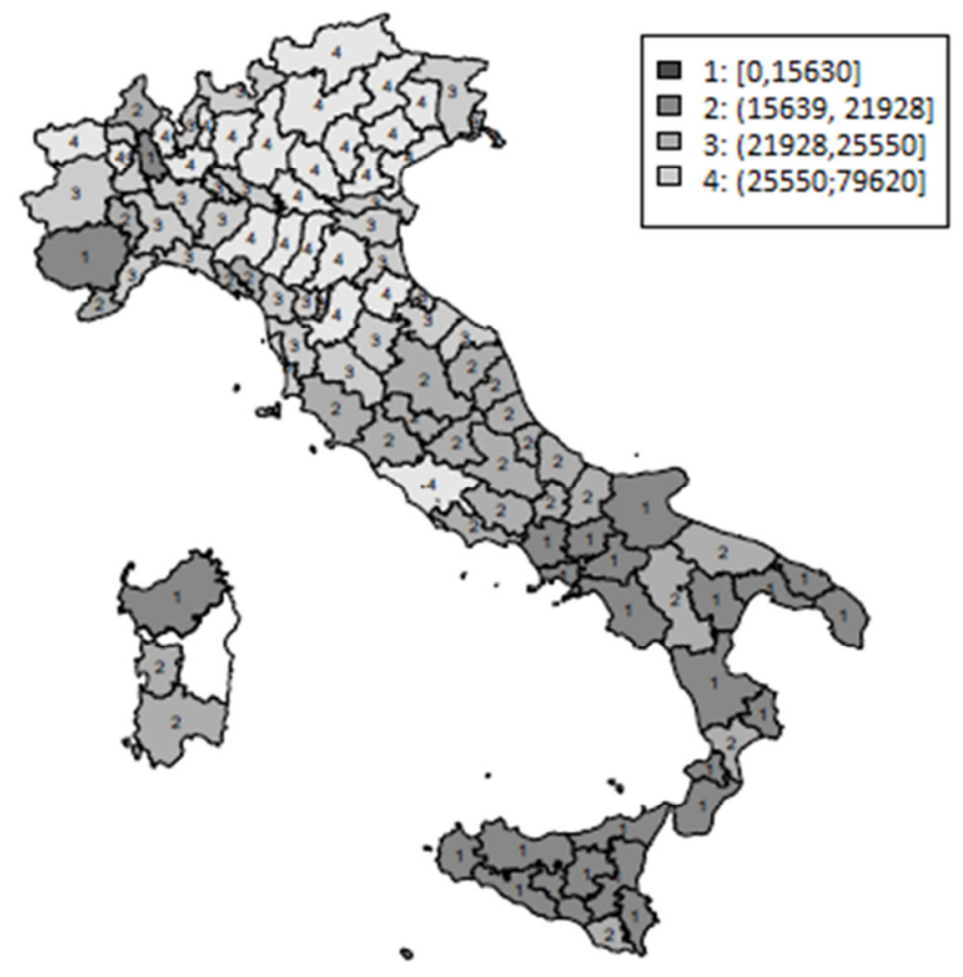

Note to Figure 1: 1-4 indicate the quartile of the distribution of per capita value added, average 2004-2007. Values in brackets are the extremes of the quartile distribution.

Figure 2 - Corruption in Italian provinces

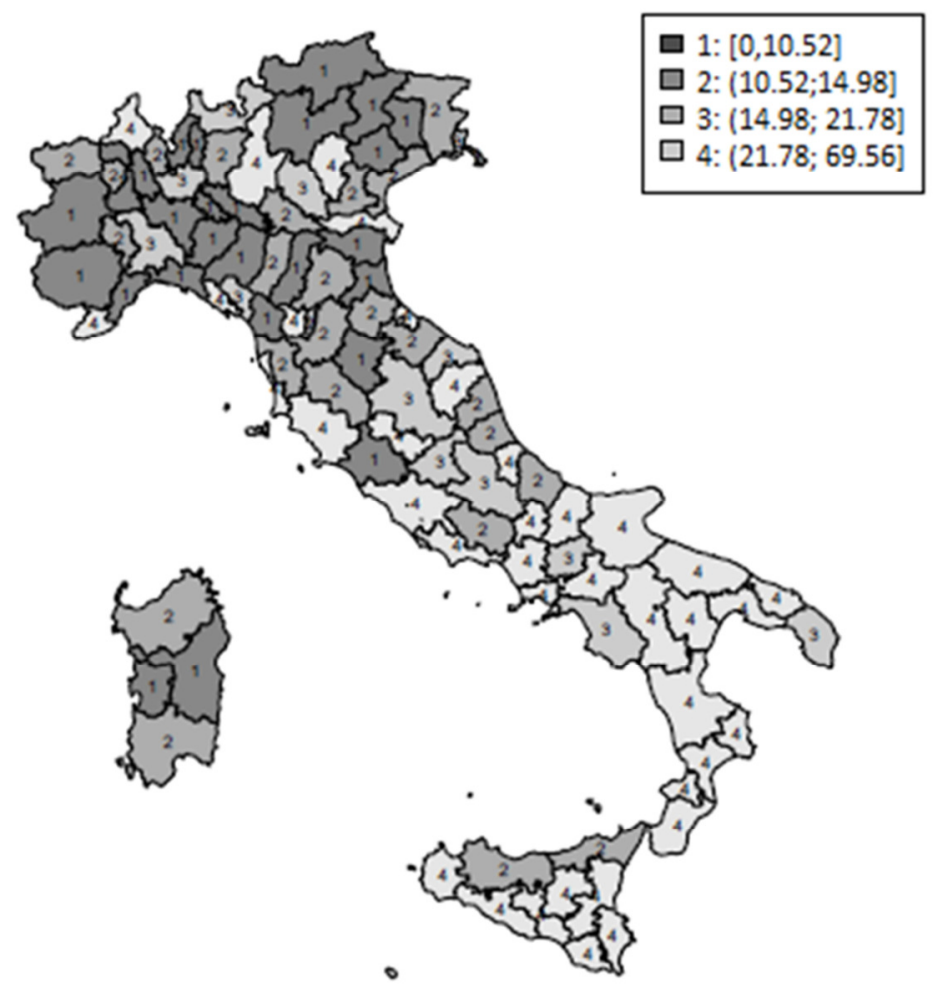

Note to Figure 2: 1-4 indicate the quartile of the distribution of provincial corruption per million of inhabitants. Values in brackets are the extremes of the quartile distribution. 
We estimate the following equation:

[1] $V A_{i}=\alpha+\beta C O R_{i}+X_{i}^{\prime} \gamma+\varepsilon_{i}$

where $V A$ is the average per capita value added at the provincial level for the years 2004 2007 (Source: ISTAT); COR is the average corruption level for the years 2004-2008, measured as the number of prosecutions for criminal association (ex art.416 and art.416 bis, Italian Penal Code, source: ISTAT); $X$ is a vector of control variables including - following the literature - the share of population with high school degree $(E D U)$ and a dummy for southern provinces $(S O U T H)$. The subscript $i=(1, \ldots, 20)$ represents the unique region identifier.

Since we suspect the presence of endogeneity between $V A$ and $C O R$, we cannot use Ordinary Least Squares in the estimation. In fact, more corrupted regions may be the less developed ones, but a high degree of economic performance attracts and incentivizes corruption. We choose to apply the Instrumental Variables (IV) regression model to control this potential endogeneity and focus on the correlation between history and corruption.

We therefore estimate equation [1] as the second stage of an IV regression model; the first stage (reduced form) is specified as follows:

[2] $\mathrm{COR}_{i}=\delta+\theta H I S T_{i}+X_{i}^{\prime} \gamma+v_{i}$

where HIST is the historical variable used to instrument COR. While choosing a proxy for HIST, we considered three different measures.

The first candidate for HIST is the set of foreign domination dummies of Di Liberto and Sideri (2011). The authors argue that different dominations can be seen as critical historical events that matter for current institutional settings but do not plausibly influence current economic performance. They introduce in their analysis a set of dummy variables that identify, for each province, the administration that occurred during the period of the Spanish domination in Italy, 1560-1659. The dummies are: AUSTRIA, PAPAL STATE, SAVOY, SPAIN, VENICE, plus a residual group of states, INDEPENDENT, that were not subject to foreign rule. Figure 3 reveals the presence of six domination clusters: Spain conquered the South, the Islands and a few provinces in the north-western part of the country; the Papal State spread from Rome, the seat of the Pope, to the other provinces of central Italy; the Savoy family reigned over the western part of Piedmont, close to the French border, while 
Austrians concentrated on the eastern one. Finally, many provinces remained independent and created free states in the central northern part. Each dominance lasted for a sufficiently long period and each province experienced the same formal government for the whole period. Moreover, as discussed in the previous Section, Spain has been often considered as having negatively affected the dominated areas. ${ }^{5}$ This measure, therefore, tests the impact of the governing rule during the Renaissance on the current level of corruption, looking for a different effect of alternative dominations.

Figure 3 - Foreign dominations

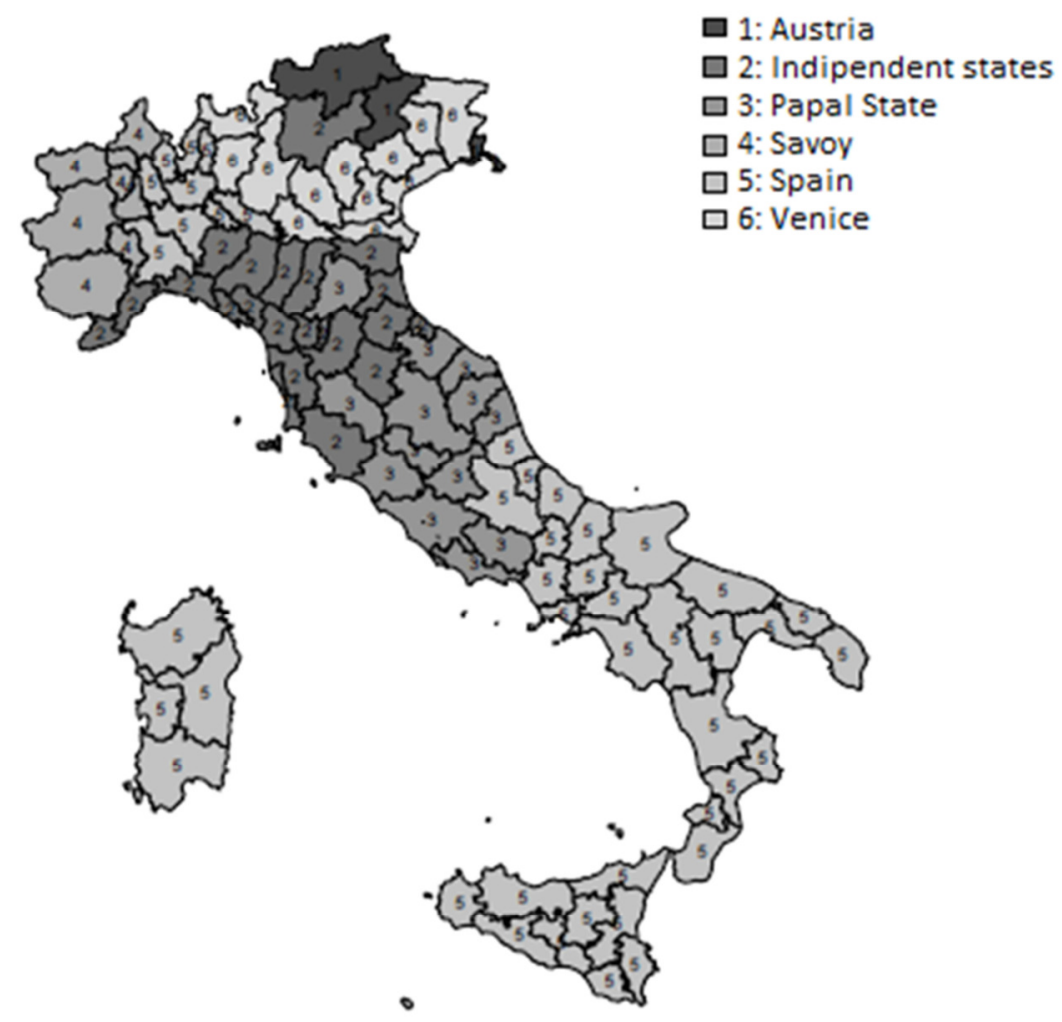

Notes to Figure 3: classification source Di Liberto and Sideri (2011)

\footnotetext{
${ }^{5}$ Di Liberto and Sideri (2011) find a significant role of past historical institutions on the current public administration efficiency (provision of health, educational infrastructures, environment and energy), and show that the latter makes a difference to the economic performance of regions.
} 
An alternative strategy ${ }^{6}$ is to use measures of social capital before and after that period. This approach is possible thanks to two classifications developed by Putnam et al. (1993): an index of autocracy $v s$. autonomous rule in circa 1300, and a scale of civicness for the early unitary period. Figure 4 pictures the five categories of autocracy, defined as: COMMUNAL REPUBLIC, EX - COMMUNAL REPUBLIC, PAPAL STATE, and KINGDOM OF SICILY. ${ }^{7}$ As the picture shows, there is a perfect coincidence between autocracy rule and dominations in central and southern Italy, although one main difference exists: the Papal State remain under the rule of the Pope in Rome, while the Kingdom of Sicily passed from the rule of the French Anjou dynasty to the one of the Spanish Aragons. The changes in the northern provinces, on the other hand, are more heterogeneous: EX - COMMUNAL REPUBLIC provinces became subject to the power of Savoy, Spain, Austria, Venice, and some remained Independent States. COMMUNAL REPUBLIC mostly maintained their independence, or fell under the government of the Papacy. This indicator allows us to test whether social capital is rooted in the medieval set-up, or if those distinctions have been overcome by later historical events. These variables refer to much ancient regimes in Italy, therefore the same reasoning done before applies here. Moreover, these variables are related with self-government and social capital, and we can expect that higher social capital brings about more monitoring and civic values, which in turn should be negatively related with corruption. ${ }^{8}$ Banfield (1958) and Putnam et al. (1993) claim that social capital is unevenly distributed in Italy according to a North-South divide, higher in the North (because of self-government) and lower in the South because of external dominations and strong preferences towards the welfare of the family as opposed to the welfare of the society. ${ }^{9}$ Guiso et al. (2010) claim that $50 \%$ of the North-South divide is explained by historical differences in social capital.

\footnotetext{
${ }^{6}$ De Blasio and Nuzzo (2010) follow similar strategies to study the effect of social capital on worker productivity, entrepreneurship and female participation.

${ }^{7}$ Some regions of current Italy (Alto Adige-Südtirol, Valle d'Aosta, Friuli Venezia Giulia and Sardinia) and two provinces (Cuneo and Turin) are not included in this index, therefore they are excluded in our estimates.

${ }^{8}$ Grießhaber and Geys (2012) find that formal forms of civic engagement - such as involvement in voluntary organizations - and social networks' characteristics (i.e. inclusive vs. exclusive and isolated vs. connected) have a significant effect on corruption in a cross-section of 20 European democracies in 2002/2003. Sabatini (2008) discusses the link between social capital and economic development.

${ }^{9}$ Cartocci (2007) provides several indicators documenting the geography of social capital in Italy.
} 
Finally, the instrument 'civicness' is a 9-scale composite indicator (that we coded from CIVIC1 to CIVIC9) including the following variables observed from the late $19^{\text {th }}$ century to the early $20^{\text {th }}$ century:

1. Membership in mutual aid societies (a factor score summarizing the membership in such societies, standardized for regional population, in 1873, 1878, 1885, 1895, and 1904);

2. Membership in cooperatives (a factor score summarizing the number of cooperatives, standardized for regional population, in 1889, 1901, 1910, and 1915);

3. Strength of the mass parties (a factor score summarizing the strength of the socialists and Catholic popolari in the national elections of 1919 and 1921, as well as their strength on local councils in this period);

4. Turnout in the few relatively open elections before Fascism brought authoritarian rule to Italy (a factor score summarizing turnout in the national elections of 1919 and 1921, as well as turnout in the local and provincial elections of 1920; these were the only elections under universal manhood suffrage before the advent of Fascism);

5. The longevity of local associations (the proportion of all local cultural and recreational organizations in the 1982 associational census that had been founded before 1860).

The geographical distribution if the civicness scale is illustrated in Figure 5. ${ }^{10}$ Once again, the index decreases moving from North to South, with the least civic Regions being the ones descending from the Kingdom of Sicily and the most civic ones Lombardia and EmiliaRomagna, a cluster of nearby provinces with mixed historical roots.

Table 1 reports the descriptive statistics of all the variables.

\footnotetext{
${ }^{10}$ A few areas of current Italy (namely Alto Adige-Südtirol, Valle d'Aosta and Friuli Venezia Giulia) are not included in this index, therefore they are excluded in our estimates.
} 
Figure 4-Autocracy rule, circa 1300

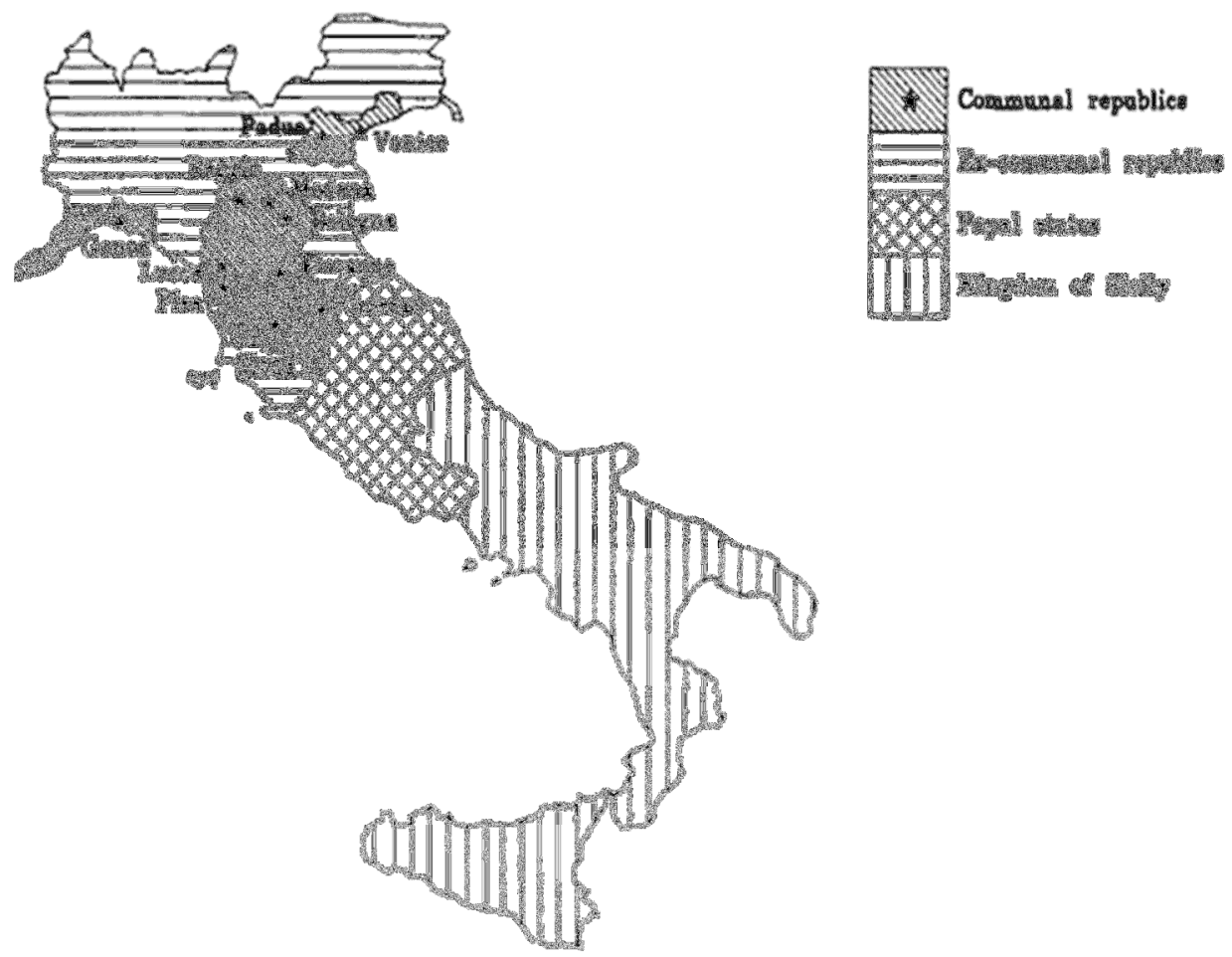

Note to Figure 4: source Putnam et al. (1993)

Figure 5 - Civicness in Italian regions

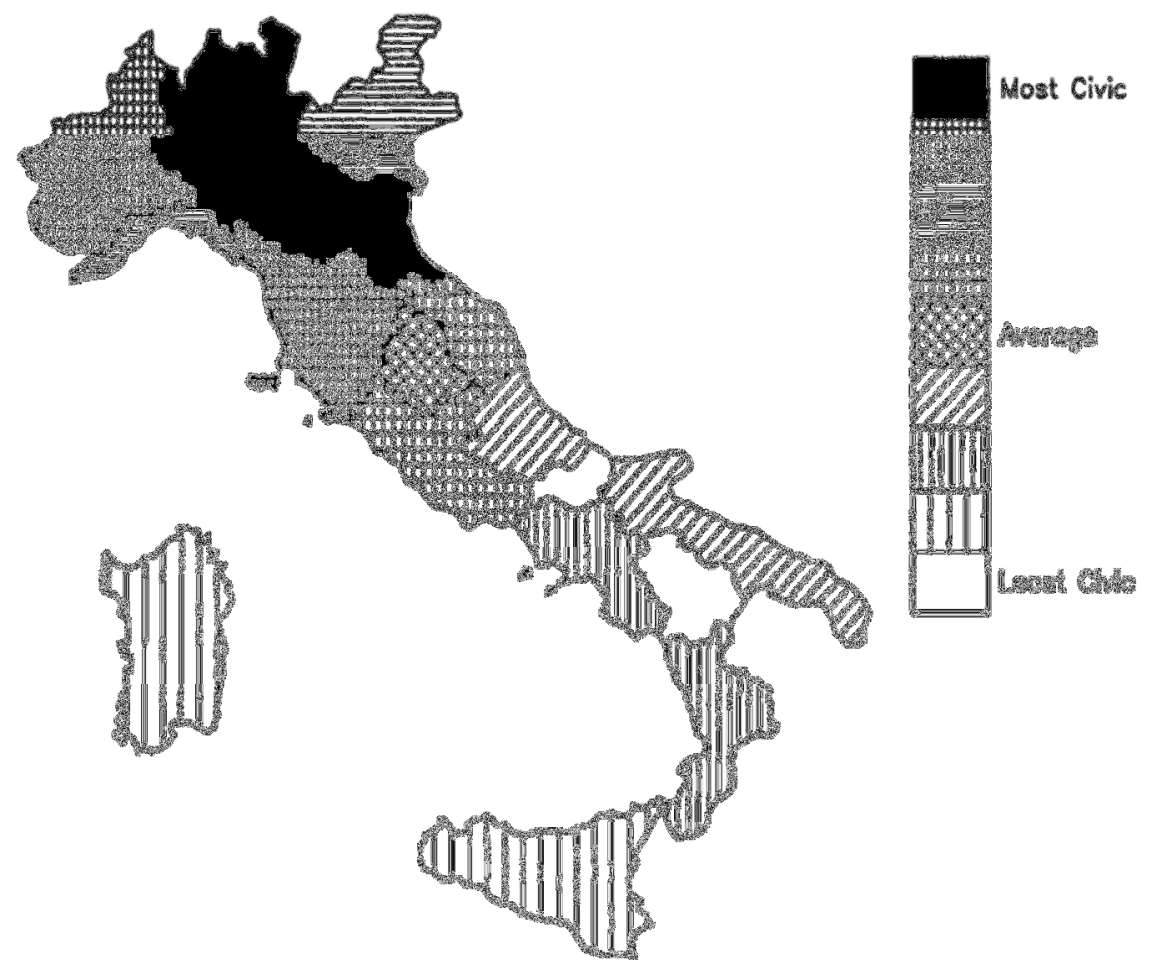

Note to Figure 5: source Putnam et al. (1993) 
Table 1 - Descriptive statistics

\begin{tabular}{|c|c|c|c|c|c|}
\hline Variable & Obs. & Mean & Std. Dev. & Min & Max \\
\hline Value added $(V A)$ & 102 & 21489.710 & 7842.539 & 11920.530 & 79623.880 \\
\hline Corruption $(C O R)$ & 103 & 2.714 & 0.541 & 1.466 & 4.242 \\
\hline Education $(E D U)$ & 103 & 31.496 & 3.393 & 25.100 & 46.290 \\
\hline South dummy (SOUTH) & 103 & 0.350 & 0.479 & 0 & 1 \\
\hline \multicolumn{6}{|c|}{ DI LIBERTO - SIDERI DOMINATIONS } \\
\hline Austria & 103 & 0.039 & 0.194 & 0 & 1 \\
\hline Independent & 103 & 0.214 & 0.412 & 0 & 1 \\
\hline Papal State & 103 & 0.126 & 0.334 & 0 & 1 \\
\hline Savoy & 103 & 0.068 & 0.253 & 0 & 1 \\
\hline Spain & 103 & 0.437 & 0.498 & 0 & 1 \\
\hline Venice & 103 & 0.117 & 0.322 & 0 & 1 \\
\hline \multicolumn{6}{|l|}{ PUTNAM AUTOCRACY } \\
\hline Communal Republic & 103 & 0.146 & 0.354 & 0 & 1 \\
\hline Ex communal Republic & 103 & 0.301 & 0.461 & 0 & 1 \\
\hline Papal State & 103 & 0.107 & 0.310 & 0 & 1 \\
\hline Kingdom of Sicily & 103 & 0.311 & 0.465 & 0 & 1 \\
\hline Other & 103 & 0.136 & 0.344 & 0 & 1 \\
\hline \multicolumn{6}{|l|}{ PUTNAM CIVICNESS } \\
\hline Civic1 & 103 & 0.039 & 0.194 & 0 & 1 \\
\hline Civic2 & 103 & 0.126 & 0.334 & 0 & 1 \\
\hline Civic3 & 103 & 0.097 & 0.298 & 0 & 1 \\
\hline Civic4 & 103 & 0.087 & 0.284 & 0 & 1 \\
\hline Civic5 & 103 & 0.019 & 0.139 & 0 & 1 \\
\hline Civic6 & 103 & 0.087 & 0.284 & 0 & 1 \\
\hline Civic7 & 103 & 0.146 & 0.354 & 0 & 1 \\
\hline Civic8 & 103 & 0.175 & 0.382 & 0 & 1 \\
\hline Civic9 & 103 & 0.194 & 0.397 & 0 & 1 \\
\hline
\end{tabular}

\section{Results}

We estimated equation [1] alternating in the first stage the historical instruments presented in the previous section.

The results are presented in Tables 2-4. Each Table reports the first stage regression estimated without covariates (Model $a$ ), with both EDU and SOUTH (Model $b$ ) and without SOUTH (Model c). The second stage regression displays six models that differ both with respect to the covariates included ${ }^{11}$ and the type of estimator employed, i.e. Two Stages Least Squares (TSLS) or Limited Information Maximum Likelihood (LIML). ${ }^{12}$

\footnotetext{
${ }^{11}$ According to this differentiation, Models 1-2 match with first stage model $a$; Models 3-4 match with first stage model $b$; Models 5-6 match with first stage model $c$.

${ }^{12}$ Since we use a small sample $(N=20)$ and more than one instrument for corruption, the TSLS estimator is biased towards OLS. The use of the LIML, that have better small sample properties than TSLS, provides a robustness check for TSLS.
} 
At first sight, the estimations prove that the choice of the instruments is a crucial decision. The first stage coefficients of Table 2, in fact, indicate that domination dummies are weak instruments because they are not robust to the introduction of additional covariates in equation [1] (Models $b$ and $c$ ). Moreover, Model $a$ shows a positive and significant correlation between corruption and only one of the dummies, namely SPAIN. This evidence is consistent with the literature (Acemoglu et al., 2001), but this dummy alone does not identify the equation ${ }^{13}$.

In contrast, the first stage coefficients of Table 3 and Table 4 suggest that autocracy dummies and civicness scale perform better, supported by the significance levels of the IV diagnostics. ${ }^{14}$ The signs of the first stage coefficients indicate, as expected, that the more autocratic territories (KINGDOM OF SICILY and PAPAL STATE) are the most corrupted, while the more independent (COMMUNAL REPUBLIC) are the least corrupted (the magnitude of the negative coefficient in Table 3 is always the larger); moreover, the most civic provinces are the least corrupted (the coefficient for CIVICl is always the largest) while the least civic ones are the most corrupted (the coefficient for CIVIC9 is always the smallest).

The first stage results, therefore, suggest that the current degree of corruption is affected mainly by the medieval governmental setting, and that following dominations have not significantly altered the social environment of the country. This legacy is more evident in Northern Italy, split by foreign dominations into separate reigns, where the Renaissance 'flag' shows no significant effect on corruption. Since in the Kingdom of Sicily the succession from the French to the Spanish crown represented a dynastic matter rather than an evolution of the administration of the territory (Acemoglu et al., 2001), the significance of the dummy SPAIN in Table 2 reasonably captures such medieval legacy. Similarly, the performance of the instrument 'civicness' is explained with the fact that it reflects the medieval autocracy borders, and we find it to be higher in less autocratic provinces. This set of instruments, however, is not robust to the introduction of the SOUTH dummy because the least civic regions are not the most southern ones, but two small regions enclosed in the peninsula, breaking the linearity of the pattern.

\footnotetext{
${ }^{13}$ We estimated a set of regressions using only SPAIN as an instrument, and the results, qualitatively and quantitatively, do not change.

${ }^{14}$ As an exception, Model $b$ in Table 4 is over-identified (Hansen J test $p$-value: 0.027).
} 
Table 2 - Per capita value added, corruption and dominations (Instruments: Domination dummies)

\begin{tabular}{|c|c|c|c|}
\hline \multicolumn{4}{|c|}{ First stage regressions, equation [2] } \\
\hline & (a) & (b) & (c) \\
\hline Dep. Var & $\ln \mathrm{COR}$ & $\ln \mathrm{COR}$ & $\ln \mathrm{COR}$ \\
\hline \multirow[t]{2}{*}{ AUSTRIA } & -0.256 & -0.310 & -0.320 \\
\hline & $(0.185)$ & $(0.193)$ & $(0.195)$ \\
\hline \multirow[t]{2}{*}{ INDEPENDENT } & -0.108 & -0.186 & -0.201 \\
\hline & $(0.159)$ & $(0.178)$ & $(0.178)$ \\
\hline \multirow[t]{2}{*}{ PAPAL STATE } & 0.165 & 0.032 & 0.005 \\
\hline & $(0.154)$ & $(0.032)$ & $(0.192)$ \\
\hline \multirow[t]{2}{*}{ SAVOY } & -0.194 & -0.164 & -0.158 \\
\hline & $(0.194)$ & $(0.204)$ & $(0.206)$ \\
\hline \multirow[t]{2}{*}{ SPAIN } & $0.342 * *$ & -0.413 & 0.255 \\
\hline & $(0.161)$ & $(0.203)$ & $(0.183)$ \\
\hline \multirow[t]{2}{*}{ EDU } & & 0.025 & $0.029 *$ \\
\hline & & $(0.017)$ & $(0.017)$ \\
\hline \multirow[t]{2}{*}{ SOUTH } & & $0.858 * * *$ & \\
\hline & & $(0.163)$ & \\
\hline \multirow[t]{2}{*}{ Constant } & $2.601 * * *$ & $1.88^{* * *}$ & $1.734 * * *$ \\
\hline & $(0.132)$ & $(0.492)$ & $(0.492)$ \\
\hline Observations & 102 & 102 & 102 \\
\hline $\mathrm{R}^{2}$ & 0.969 & 0.977 & 0.970 \\
\hline Underidentification test: Kleibergen-Paap rk LM statistic ( $\mathrm{p}$-value) & 0.005 & 0.111 & 0.014 \\
\hline \multicolumn{4}{|l|}{ Weak-instrument-robust-inference } \\
\hline Anderson-Rubin Wald test (p-value) & 0.000 & 0.000 & 0.000 \\
\hline Anderson-Rubin Wald test (p-value) & 0.000 & 0.000 & 0.000 \\
\hline Stock-Wright LM S statistic (p-value) & 0.000 & 0.000 & 0.000 \\
\hline Over-identification test: Hansen J test (p-value) & 0.375 & 0.000 & 0.375 \\
\hline
\end{tabular}

\begin{tabular}{lllllll}
\hline \hline \multicolumn{7}{c}{ Second stage regressions, equation [1] } \\
\hline Estimation method & TSLS & LIML & TSLS & LIML & TSLS & LIML \\
\hline Dep. Var & $\ln V A$ & $\ln V A$ & $\ln V A$ & $\ln V A$ & $\ln V A$ & $\ln V A$ \\
\hline ln COR & $-0.895^{* * *}$ & $-1.013^{* * *}$ & -0.024 & 7.588 & $-0.941^{* * *}$ & $-1.145^{* * *}$ \\
& $(0.203)$ & $(0.236)$ & $(0.165)$ & $(69.69)$ & $(0.210)$ & $(0.291)$ \\
EDU & & & 0.004 & -0.204 & $0.0299^{*}$ & $0.0371^{* *}$ \\
& & & $(0.009)$ & $(1.905)$ & $(0.016)$ & $(0.019)$ \\
SOUTH & & & $-0.480^{* * *}$ & -4.964 & & \\
& & & $(0.096)$ & $(41.05)$ & & \\
Constant & $12.37^{* * *}$ & $12.68^{* * *}$ & $10.03^{* * *}$ & -2.604 & $11.55^{* * *}$ & $11.87^{* * *}$ \\
& $(0.547)$ & $(0.645)$ & $(0.379)$ & $(115.7)$ & $(0.598)$ & $(0.681)$ \\
Observations & 102 & 102 & 102 & 102 & 102 & 102 \\
$\mathrm{R}^{2}$ & 0.998 & 0.997 & 0.999 & 0.886 & 0.998 & 0.997 \\
\hline
\end{tabular}

Notes to Table 2. First stage regressions are the same for TSLS (Two Stages Least Squares) and LIMS (Limited Information Maximum Likelihood). Robust standard errors in parentheses. ${ }^{* * *} \mathrm{p}<0.01$. ${ }^{* *} \mathrm{p}<0.05 .{ }^{*} \mathrm{p}<0.1$ 
Table 3 - Per capita value added, corruption and autocracy (Instruments: Putnam autocracy)

\begin{tabular}{|c|c|c|c|c|c|c|}
\hline \multicolumn{7}{|c|}{ First stage regressions, equation [2] } \\
\hline & & & & (a) & (b) & (c) \\
\hline \multicolumn{4}{|l|}{ Dep.Var } & $\ln \mathrm{COR}$ & $\ln \mathrm{COR}$ & $\ln \mathrm{COR}$ \\
\hline \multicolumn{4}{|c|}{ COMMUNAL REPUBLIC } & $\begin{array}{l}-0.736 \text { *** } \\
(0.106)\end{array}$ & $\begin{array}{l}-0.759 * * * \\
(0.278)\end{array}$ & $\begin{array}{l}-0.734 * * * \\
(0.109)\end{array}$ \\
\hline \multicolumn{4}{|c|}{ EX COMMUNAL REPUBLIC } & $\begin{array}{l}-0.703 * * * \\
(0.116)\end{array}$ & $\begin{array}{l}-0.705 * * \\
(0.282)\end{array}$ & $\begin{array}{l}-0.679 * * * \\
(0.116)\end{array}$ \\
\hline \multicolumn{4}{|l|}{ PAPAL STATE } & $\begin{array}{l}-0.385 * * * \\
(0.115)\end{array}$ & $\begin{array}{l}-0.433 \\
(0.283)\end{array}$ & $\begin{array}{l}-0.408 * * * \\
(0.119)\end{array}$ \\
\hline \multicolumn{4}{|l|}{ PUT_OUT } & $\begin{array}{l}-0.915 * * * \\
(0.135)\end{array}$ & $\begin{array}{l}-0.910 * * * \\
(0.235)\end{array}$ & $\begin{array}{l}-0.890 \text { *** } \\
(0.132)\end{array}$ \\
\hline \multicolumn{4}{|l|}{ EDU } & & $\begin{array}{l}0.012 \\
(0.012)\end{array}$ & $\begin{array}{l}0.012 \\
(0.012)\end{array}$ \\
\hline \multicolumn{4}{|l|}{ SOUTH } & & $\begin{array}{l}-0.026 \\
(0.258)\end{array}$ & \\
\hline \multicolumn{4}{|l|}{ Constant } & $\begin{array}{l}3.203 * * * \\
(0.078)\end{array}$ & $\begin{array}{l}2.851 * * * \\
(0.453)\end{array}$ & $\begin{array}{l}2.822 * * * \\
(0.378)\end{array}$ \\
\hline \multicolumn{4}{|l|}{ Observations } & 102 & 102 & 102 \\
\hline \multicolumn{4}{|l|}{$\mathrm{R}^{2}$} & 0.979 & 0.979 & 0.979 \\
\hline \multicolumn{4}{|c|}{ Underidentification test: Kleibergen-Paap rk LM statistic (p-value) } & 0.000 & 0.013 & 0.000 \\
\hline \multicolumn{7}{|c|}{ Weak-instrument-robust-inference } \\
\hline \multicolumn{4}{|c|}{ Anderson-Rubin Wald test (p-value) } & 0.000 & 0.001 & 0.000 \\
\hline \multicolumn{4}{|c|}{ Anderson-Rubin Wald test ( $\mathrm{p}$-value) } & 0.000 & 0.000 & 0.000 \\
\hline \multicolumn{4}{|c|}{ Stock-Wright LM S statistic (p-value) } & 0.000 & 0.043 & 0.000 \\
\hline \multicolumn{4}{|c|}{ Over-identification test: Hansen J test ( $\mathrm{p}$-value) } & 0.087 & 0.054 & 0.137 \\
\hline \multicolumn{7}{|c|}{ Second stage regressions, equation [1] } \\
\hline & TSLS & LIML & TSLS & LIML & $T S L S$ & LIML \\
\hline & (1) & (2) & (3) & (4) & (5) & (6) \\
\hline Estimation method & $T S L S$ & LIML & TSLS & LIML & $T S L S$ & LIML \\
\hline Dep. Var & $\ln V A$ & $\ln V A$ & $\ln V A$ & $\ln V A$ & $\ln V A$ & $\ln V A$ \\
\hline $\ln \mathrm{COR}$ & $\begin{array}{l}-0.600 \text { *** } \\
(0.091)\end{array}$ & $\begin{array}{l}-0.672 * * * \\
(0.103)\end{array}$ & $\begin{array}{l}-0.171 * * \\
(0.076)\end{array}$ & $\begin{array}{l}-0.230^{*} \\
(0.130)\end{array}$ & $\begin{array}{l}-0.646 * * * \\
(0.088)\end{array}$ & $\begin{array}{l}-0.733 \text { *** } \\
(0.116)\end{array}$ \\
\hline EDU & & & $\begin{array}{l}0.008 \\
(0.009)\end{array}$ & $\begin{array}{l}0.009 \\
(0.007)\end{array}$ & $\begin{array}{l}0.0195^{*} \\
(0.012)\end{array}$ & $\begin{array}{l}0.0226 * * \\
(0.0113)\end{array}$ \\
\hline SOUTH & & & $\begin{array}{l}-0.394 * * * \\
(0.06)\end{array}$ & $\begin{array}{l}-0.359 * * * \\
(0.087)\end{array}$ & & \\
\hline Constant & $\begin{array}{l}11.56^{* * * *} \\
(0.255)\end{array}$ & $\begin{array}{l}11.76 * * * \\
(0.282)\end{array}$ & $\begin{array}{l}10.27 * * * \\
(0.263)\end{array}$ & $\begin{array}{l}10.37 * * * \\
(0.286)\end{array}$ & $\begin{array}{l}11.07 * * * \\
(0.457)\end{array}$ & $\begin{array}{l}11.21 * * * \\
(0.384)\end{array}$ \\
\hline Observations & 102 & 102 & 102 & 102 & 102 & 102 \\
\hline $\mathrm{R}^{2}$ & 0.999 & 0.998 & 0.999 & 0.886 & 0.97 & 0.997 \\
\hline
\end{tabular}

Notes to Table 3. First stage regressions are the same for TSLS (Two Stages Least Squares) and LIMS (Limited Information Maximum Likelihood). Robust standard errors in parentheses. $* * * p<0.01 . * * p<0.05$. ${ }^{*} \mathrm{p}<0.1$ 
Table 4 - Per capita value added, corruption and civicness (Instruments: Putnam civicness)

\begin{tabular}{|c|c|c|c|}
\hline \multicolumn{4}{|l|}{ First stage regressions, equation [2] } \\
\hline & (a) & (b) & (c) \\
\hline Dep.Var & $\ln \mathrm{COR}$ & $\ln \mathrm{COR}$ & $\ln \mathrm{COR}$ \\
\hline CIVIC 1 & $\begin{array}{l}1.429 * * * \\
(0.243)\end{array}$ & $\begin{array}{l}0.775 * * * \\
(0.261)\end{array}$ & $\begin{array}{l}1.378 * * * \\
(0.258)\end{array}$ \\
\hline CIVIC 2 & $\begin{array}{l}0.532 * * * \\
(0.196)\end{array}$ & $\begin{array}{l}-0.087 \\
(0.196)\end{array}$ & $\begin{array}{l}0.516^{* *} \\
(0.207)\end{array}$ \\
\hline CIVIC 3 & $\begin{array}{l}0.819 * * * \\
(0.165)\end{array}$ & $\begin{array}{l}0.171 \\
(0.183)\end{array}$ & $\begin{array}{l}0.774 * * * \\
(0.182)\end{array}$ \\
\hline CIVIC 4 & $\begin{array}{l}0.639 * * * \\
(0.186)\end{array}$ & & $\begin{array}{l}0.603 * * * \\
(0.182)\end{array}$ \\
\hline CIVIC 5 & $\begin{array}{l}0.572 * * * \\
(0.153)\end{array}$ & $\begin{array}{l}0.506 * * * \\
(0.186)\end{array}$ & $\begin{array}{l}0.506^{* * *} \\
(0.186)\end{array}$ \\
\hline CIVIC 6 & $\begin{array}{l}0.411^{* *} \\
(0.157)\end{array}$ & $\begin{array}{l}0.357 * \\
(0.181)\end{array}$ & $\begin{array}{l}0.357 * \\
(0.180)\end{array}$ \\
\hline CIVIC 7 & $\begin{array}{l}0.166 \\
(0.175)\end{array}$ & $\begin{array}{l}0.138 \\
(0.188)\end{array}$ & $\begin{array}{l}0.138 \\
(0.188)\end{array}$ \\
\hline CIVIC 8 & $\begin{array}{l}0.153 \\
(0.145)\end{array}$ & $\begin{array}{l}0.137 \\
(0.153)\end{array}$ & $\begin{array}{l}0.137 \\
(0.152)\end{array}$ \\
\hline CIVIC 9 & $\begin{array}{l}-0.047 \\
(0.156)\end{array}$ & $\begin{array}{l}-0.070 \\
(0.163)\end{array}$ & $\begin{array}{l}-0.070 \\
(0.163)\end{array}$ \\
\hline EDU & & $\begin{array}{l}0.010 \\
(0.015)\end{array}$ & $\begin{array}{l}0.010 \\
(0.015)\end{array}$ \\
\hline SOUTH & & $\begin{array}{l}0.603 * * * \\
(0.163)\end{array}$ & \\
\hline Constant & $\begin{array}{l}2.378 * * * \\
(0.120)\end{array}$ & $\begin{array}{l}2.087 * * * \\
(0.442)\end{array}$ & $\begin{array}{l}2.087 * * * \\
(0.442)\end{array}$ \\
\hline Observations & 102 & 102 & 102 \\
\hline $\mathrm{R}^{2}$ & 0.979 & 0.979 & 0.979 \\
\hline $\begin{array}{l}\text { Underidentification test: Kleibergen-Paap rk LM statistic (p-value) } \\
\text { Weak-instrument-robust-inference }\end{array}$ & 0.0001 & 0.069 & 0.0004 \\
\hline Anderson-Rubin Wald test (p-value) & 0.000 & 0.000 & 0.000 \\
\hline Anderson-Rubin Wald test (p-value) & 0.000 & 0.000 & 0.000 \\
\hline Stock-Wright LM S statistic (p-value) & 0.000 & 0.000 & 0.000 \\
\hline Over-identification test: Hansen J test (p-value) & 0.062 & 0.027 & 0.134 \\
\hline
\end{tabular}

\begin{tabular}{|c|c|c|c|c|c|c|}
\hline \multicolumn{7}{|c|}{ Second stage regressions, equation [1] } \\
\hline & (1) & (2) & (3) & (4) & (5) & (6) \\
\hline Estimation method & $T S L S$ & LIML & $T S L S$ & LIML & $T S L S$ & LIML \\
\hline Dep. Var & $\ln V A$ & $\ln V A$ & $\ln V A$ & $\ln V A$ & $\ln V A$ & $\ln V A$ \\
\hline $\ln \mathrm{COR}$ & $\begin{array}{l}-0.578 * * * \\
(0.099)\end{array}$ & $\begin{array}{l}-0.741 * * * \\
(0.116)\end{array}$ & $\begin{array}{l}-0.161 \\
(0.102)\end{array}$ & $\begin{array}{l}-0.313^{*} \\
(0.162)\end{array}$ & $\begin{array}{l}-0.626 * * * \\
(0.110)\end{array}$ & $\begin{array}{l}-0.799 * * * \\
(0.129)\end{array}$ \\
\hline EDU & & & $\begin{array}{l}0.008 \\
(0.009)\end{array}$ & $\begin{array}{l}0.012 \\
(0.008)\end{array}$ & $\begin{array}{l}0.019 \\
(0.013)\end{array}$ & $\begin{array}{l}0.025^{* *} \\
(0.012)\end{array}$ \\
\hline SOUTH & & & $\begin{array}{l}-0.400^{* * * *} \\
(0.069)\end{array}$ & $\begin{array}{l}-0.310^{* * * *} \\
(0.106)\end{array}$ & & \\
\hline Constant & $\begin{array}{l}11.50 * * * \\
(0.270)\end{array}$ & $\begin{array}{l}11.95^{* * *} \\
(0.319)\end{array}$ & $\begin{array}{l}10.26^{* * *} \\
(0.248)\end{array}$ & $\begin{array}{l}10.51 * * * \\
(0.338)\end{array}$ & $\begin{array}{l}11.04 * * * \\
(0.433)\end{array}$ & $\begin{array}{l}11.32 * * * \\
(0.414)\end{array}$ \\
\hline Observations & 102 & 102 & 102 & 102 & 102 & 102 \\
\hline $\mathrm{R}^{2}$ & 0.999 & 0.998 & 0.999 & 0.999 & 0.998 & 0.998 \\
\hline
\end{tabular}

Notes to Table 4. First stage regressions are the same for TSLS (Two Stages Least Squares) and LIMS (Limited Information Maximum Likelihood). Robust standard errors in parentheses. *** $\mathrm{p}<0.01$. ${ }^{* *} \mathrm{p}<0.05 .{ }^{*} \mathrm{p}<0.1$ 
If we look at the second stage regressions, we can see that the TSLS estimations are robust to the use of $L I M L$. In Table 3 the coefficients associated to COR are negative as expected and always significant, estimating that a $10 \%$ increase in corruption causes about $6 \%$ decrease in per capita provincial value added. This elasticity reduces to about $2,3 \%$ when the South dummy is included (Models 3-4). Southern regions have a provincial value added about 35\% lower than the other Regions, and they belong to the highest quartiles of corruption; therefore, the SOUTH dummy washes away all the unobserved factors that hamper growth in the South that is not explained by the historically-driven corruption and reduces the elasticity (i.e. the asymmetric development of the infrastructures in the last century in Italy).

In Table 4, the coefficient of corruption is negative and the elasticity is higher than $6 \%$ in those models excluding SOUTH, and about 3\% when it is introduced. However, Model $b$ shows a significant correlation between SOUTH and corruption, casting doubts on the robustness of the validity of the civicness scale as an instrument.

Finally, the covariates behave as expected: an increase in the quality of the human capital $(E D U)$ is associated to a $2 \%$ increase in the economic performance, but it loses significance once the SOUTH dummy is included. This dummy, as already commented, is always negative and significant.

\section{Conclusions}

We investigated the relationship between corruption and economic performance, focusing on the historical roots of the former. We empirically tested this hypothesis on a dataset of Italian provinces, and addressed the possible endogeneity of corruption by applying an IV model, checking the robustness of $T L S$ by using also the $L I M L$ estimator. We alternatively used three sets of historical instruments for corruption: 1) foreign dominations that ruled Italian regions between the $16^{\text {th }}$ and $17^{\text {th }}$ century, 2) autocracy/autonomous rule in the $14^{\text {th }}$ century, and 3 ) an index of social capital between the end of the $19^{\text {th }}$ and at the onset of the $20^{\text {th }}$ century. The results of the first stage equation confirm the validity of the set of instruments 2) and 3), suggesting that the most relevant legacy is the medieval one, and that foreign dominations did not alter the heterogeneous distribution of the social capital in the country. As expected, corruption is larger in those provinces that experienced more autocratic governments in 1300 
circa and were characterized with a low level of civicness during the early unified period, ranging from the late $19^{\text {th }}$ century to the early $20^{\text {th }}$ century.

The second stage regression coefficients indicate a significant impact of historicallydriven corruption on development: a $10 \%$ increase in corruption is associated in our dataset to a decrease of the provincial value added of about $25 \%$. All in all, this study verifies the hypothesis that history affects economic performance by determining the degree of corruption. 


\section{References}

Acemoglu D. (2005). Modelling Inefficient Institutions, Advances in Economic Theory, Proceedings of 2005 World Congress, edited by Blundell R., Newey W. and Persson T., Cambridge University Press, London, 341-380.

Acemoglu D. and Robinson J. (2012). Why Nations Fails. The Origins of Power, Prosperity and Poverty, Profile Books, London.

Acemoglu D. and Robinson J. (2008). Persistence of Power, Elites and Institutions, American Economic Review 98: 267-93.

Acemoglu, D., S. Johnson and J. A. Robinson (2001). The Colonial Origins of Comparative Development: An Empirical Investigation, American Economic Review, 91, 13691401.

Acemoglu, D., Johnson, S. and Robinson, J.A. (2003). An African Success Story: Botswana, in D. Rodrik (ed.) In Search of Prosperity: Analytic Narratives on Economic Growth, Princeton University Press, pp. 80-122.

Banfield, E. (1958). The Moral Basis of a Backward Society, Free Press, New York.

Besley, T. and Persson, T. (2009). The origins of state capacity: Property rights, taxation, and policy, American Economic Review, 99: 1218-1244.

Cartocci, R. (2007), Mappe del tesoro. Atlante del capitale sociale in Italia. Il Mulino, Bologna.

De Blasio, G. and Nuzzo, G. (2010). Historical traditions of civicness and local economic development, Journal of Regional Science, 20, 1-29.

Djankov S., La Porta R., Lopez-de-Silanes F. and Shleifer A. (2003). Courts, The Quarterly Journal of Economics 118: 453-517.

Di Liberto, A. and M. Sideri (2011). Past Dominations, Current Institutions and the Italian Regional Economic Performance, Working Paper CRENoS n. 201115, Center for North South Economic Research, University of Cagliari and Sassari.

Fiorino, N., Galli, E., Petrarca, I. (2012). Corruption and Growth: Evidence from the Italian Regions. European Journal of Government and Economics, 2: 106-125.

Glaeser, E.L., R. La Porta, F. Lopez-de-Silanes and A. Shleifer (2004). Do Institutions Cause Growth? Journal of Economic Growth, 9: 271-303.

Grießhaber, N. and Geys, B. (2012). Civic engagement and corruption in 20 European democracies, European Societies, 14: 57-81.

Guiso, L., Sapienza, P. and Zingales, L. (2010). Long-Term Persistence, CEPR Discussion 
Papers 6981.

Knack S. and Keefer P. (1995). Institutions and economic performance: cross country tests using alternative institutional measures, Economics and Politics 7: 207-27.

Krueger A. O. (1974). The Political Economy of the Rent-seeking Society, American Economic Review 64: 291-303.

Kugler, M., Verdier, T., and Zenou, Y. (2005). Organized crime, corruption and punishment, Journal of Public Economics, 89: 1639- 1663

La Porta R., Lopez-de-Silanes F., Shleifer A. and Vishny R. (1998). Law and Finance, Journal of Political Economy 106: 1113-1155.

La Porta R., Lopez-de-Silanes F., Schleifer A. and Vishny R. (1999). The Quality of Government, Journal of Law, Economics and Organization 15: 222-279.

March J. G.. and Olsen J. P. (2006). Elaborating the New Institutionalism, in: Rhodes R. A. W., Binder S. A. and Rockman B. A (eds.) Oxford Handbooks of Political Science, Oxford University Press, New York.

Mauro P. (1995). Corruption and Growth, The Quarterly Journal of Economics 110: 681-712.

Murrell, P., and Schmidt, M. (2011). The Coevolution of Culture and Institutions in Seventeenth Century England, mimeo, University of Maryland.

Putnam, R., Leonardi, R. and Nanetti, R.Y. (1993). Making Democracy Work, Simon \& Schuster, New York.

Rodrik, D., Subramanian, A. and Trebbi F. (2004). Institutions Rule: The Primacy of Institutions over Geography and Integration in Economic Development, Journal of Economic Growth, 9: 131-165.

Sabatini, F. (2008). Social Capital and the Quality of Economic Development, Kyklos, 61, 466-499.

Shleifer A. and Vishny R. (1993). Corruption, The Quarterly Journal of Economics 108: 599617.

Tanzi V. (1998). Corruption Around the World: Causes, Consequences, Scope, and Cures, IMF Staff Papers 98/63. 